\title{
Pembelajaran Kitab Mafahim dalam Meningkatkan Faham Ahlus Sunnah Wal Jama'ah Santri Di Pondok Pesantren Miftahul Ulum Tempuran Bantaran Probolinggo
}

\author{
Budi Hartono ${ }^{1}$, Benny Prasetiya ${ }^{2}$, Ari Susandi ${ }^{3}$ \\ Sekolah Tinggi Agama Islam Muhammadiyah Probolinggo \\ * Corresponding Author. E-mail: \\ csantony48@gmail.com,prasetiyabenny@gmail.com,pssandi8@gmail.com
}

\begin{abstract}
Receive: $13 / 07 / 2021$
Accepted: 23/07/2021

Published: 04/10/2021

Abstrak

Madrasah ialah salah satu tipe pembelajaran Islam Indonesia yang bertabiat konvensional buat menguasai, mendalami, serta mengamalkan anutan Islam dengan menekankan berartinya akhlak agama Islam selaku prinsip hidup tiap hari. Dalam kehidupan beriktikad banyak terangkai problematika sekitar analogi. Perbandingan itu berbentuk perbandingan penerapan amaliah serta kultur.Solusi untuk mengatasi permasalahan adalah dengan mengajarkan Islam damai, Islam toleran, dan Islam yang sesuai dengan ajaran Nabi Muhammad SAW (ahlussunnah wal jamaah). Ada pula tujuan dari penelitian ini ialah: Mendefinisikan pemograman penataran Kitab Mafahim dalam tingkatkan faham Ahlus Sunnah wal Jama' ah. Mendefinisikan penerapan penataran buku Mafahim dalam tingkatkan faham Ahlus Sunnah wal Jama' ah. Mendeskripsikan evaluasi pembelajaran kitab Mafahim dalam meningkatkan faham Ahlus Sunnah wal Jama'ah.Pendekatan yang digunakan dalam penelitian ini adalah pendekatan kualitatif deskriptif karena penelitian yang akan dilakukan akan berusaha mendeskripsikan tentang pembelajaran kitab mafahim dalam meningkatkan faham ahlus sunnah wal jama'ah santri di pondok pesantren Miftahul Ulum, Tempuran, Probolinggo, alasan menggunakan pendekatan ini karena data yang dikaji atau diteliti berbentuk perkata tercatat ataupun perkataan dari banyak orang ataupun sikap yang dicermati. Dari hasil riset bisa disimpulkan kalau dalam melakukan penataran wajib melaksanakan suatu pemograman penataran dengan membagikan bimbingan, memotivasi santri biar santri dapat aktif, inovatif, serta suka kala cara penataran. Kemudian dilakukan sebuah pelaksanaan pembelajaran dengan sistem yang telah direncanakan. Yang terakhir evaluasi pembelajaran yang dilakukan diakhir pembelajaran yaitu pada waktu semesteran dengan memberikan tes tulis dan pengamatan langsung terhadap santri.
\end{abstract}

Kata Kunci: Pembelajaran, Kitab Mafahim, Ahlussunnah Wal Jamaah

\begin{abstract}
Madrasah is one type of Indonesian Islamic learning that is conventional in nature to master, explore, and practice Islamic teachings by emphasizing the importance of Islamic religious morality as a principle of daily life. In life with intention, many problems are strung around analogies. The comparison is in the form of a comparison of the application of amaliah and culture. The solution to overcome the problem is to teach peaceful Islam, tolerant Islam, and Islam that is in accordance with the teachings of the Prophet Muhammad (Ahlussunnah wal Jamaah). There is also a goal of this research, namely: To define the program for upgrading the Book of Mafahim in improving the understanding of Ahlus Sunnah wal Jama'ah. Define the application of Mafahim book upgrading in improving understanding of Ahlus Sunnah wal Jama'ah. Describes the evaluation of learning the Mafahim book in improving the understanding of Ahlus Sunnah wal Jama'ah. The approach used in this study is a descriptive qualitative approach because the research that will be carried out will try to describe the learning of the Mafahim book in improving the understanding of Ahlus Sunnah wal Jama'ah santri in Islamic boarding schools Miftahul Ulum, Tempuran, Probolinggo, the reason for using this approach is because the data being studied or researched is in the form of recorded words or words from many people or attitudes that are observed. From the research results, it can be concluded that in conducting upgrading, it is mandatory to carry out an upgrading program by providing guidance, motivating students so that students can be active, innovative, and like the way of upgrading. Then carried out an implementation of learning with the system that has been planned. The last evaluation of learning is carried out at the end of the lesson, namely at the time of the semester by giving written tests and direct observations of students.
\end{abstract}

Keywords: Learning, Mafahim Book, Ahlussunnah Wal Jamaah.

\section{Pendahuluan}

Pennyelenggaraan badan pembelajaran madrasah berupa tempat menginap ialah komunitas tertentu di dasar arahan kyai ataupun malim dibantu oleh seseorang ataupun sebagian orang malim, serta ataupun para ustadz yang hidup bersama di tengah- tengah para santri dengan langgar ataupun surau selaku pusat aktivitas ritual keimanan. Di sisi itu, gedungbangunan sekolah ataupun ruang- ruang berlatih selaku pusat aktivitas berlatih membimbing, dan pondok- pondok selaku tempat bermukim santri. 
Sepanjang 24 jam, dari era ke era mereka hidup beramai- ramai antara kyai, ustadz, santri serta para penjaga madrasah yang lain, selaku satu keluarga besar. (Syafe'i, 2017)

Perihal ini sejalan dengan penadapat Ari Susandi yakni kecerdasan emosional ialah kombinasi keahlian penuh emosi serta sosial. Seorang yang memiliki pengetahuan (keceredasan emosional) mampu mengatasi permasalahan yang terjalin didalam kehidupan sebab umumnya orang yang memiliki pengetahuan (keceredasan emosional) memiliki pemahaman pada emosinya.(Susandi, 2016)

Penataran pada Pondok madrasah amat sama dengan kitab- kitab klasik ataupun yang diucap pula dengan buku kuning serta pengajarannya sedang memakai sistem halaqoh. Halaqoh dari bidang kebahasaan berarti“ lingkarangan anak didik ataupun bundaran berlatih santri ialah sebagian orang santri dengan jumlah khusus membuat halaqoh yang dipandu langsung oleh seseorang ajengan ataupun ajengan ataupun pula santri tua buat mangulas ataupun menelaah sesuatu perkara yang sudah didetetapkan tadinya".Jadi, santri bersandar bersila mengitari ustadz yang membimbing sembari mencermati pengajian yang di informasikan oleh ustadz itu. (Rasikh, 2018)

Selaku badan pembelajaran, madrasah mempunyai ideal serta adat- istiadat keilmuan yang berlainan dibanding dengan badan yang lain. Diantara karakteristik khas dari pondok madrasah merupakan isi kurikulum yang terfokus pada ilmuilmu agama. Kitab kuning jadi sebutan yang sama dengan madrasah. Oleh sebab buku kuning jadi referensi penting serta jadi salah satu bagian untuk madrasah. Dengan bahasa ekstremnya, sesuatu badan tidak bisa dibilang selaku madrasah bila di dalamnya tidak menelaah buku kuning. Perihal ini membuktikan alangkah akrab ikatan antara madrasah serta buku kuning. Adab yg penting, kuat, serta kokoh, pula jiwa yang besar, gandrung serta ambisius, amat diperlukan oleh tiap insan.(Devy Habibi, Harimulyo, Prasetya and Muhammad, 2021). Namun kelihatannya penataran di lembaga(sekolah ataupun perguruan) lebih mengedepankan arah kognitif serta kurang meletakkan atensi arah afektif.(Prasetiya, Rofi and Setiawan, 2018).
Pengajian' Kiab Kuning' ataupun'Kitab tanpa berharokat' ini ialah perihal yang amat berarti dalam pembelajaran madrasah, karena ini jadi novel pegangan. Tipe'Kitab Kuning' ataupun'Kitab tanpa berharokat' selaku kesusastraan yang dipakai di badan pembelajaran Islam konvensional madrasah amat terbatas jumlahnya. Pengelompokan kitab- kitab itu bisa diklasifikasikan kedalam aspek ilmu- ilmu syari' at serta ilmu- ilmu non- syari' at.(Akbar and Ismail, 2018)

Dalam madrasah buku kuning memanglah sangat berkuasa. Beliau tidak saja selaku khasanah keilmuan, namun pula selaku sistem angka yang dipegangi serta memberi warna semua pandangan kehidupan. Buku kuning mewujud dalam mengerti keimanan, aturan metode, ritual, pergaulan, etik serta metode penglihatan kehidupan masyarakat madrasah serta warga pengikutnya. Dalam realitas ini buku kuning ialah adat- istiadat yang hidup selaku' kebudayaan santri' yang lumayan produktif dalam warga Indonesia. Serta selaku adat- istiadat itu pula buku kuning hidup dalam sejarahnya yang kekal, melewati keberadaannya selaku khasanah keilmuan. Diamati dari ranah keturunannya, wawasan keagamaan, toleransi, rasa gotong royong, budi pekerti, kebaikan serta sifat bijaksananya sepanjang hidup betul- betul menberikan ilustrasi yang cocok mengenai yang di ajarkan pada peserta didik ataupun santrinya serta pula pada warga sekelilingnya.(Khosiah, 2020)

Menekuni Kitab ialah sesuatu masalah yang amat berarti untuk orang mukmin, sebab buku ialah salah satu pangkal rujukan dalam menata gerak- gerik serta aksi lakunya seseorang mukmin. Kitab- kitab yang dapat dijadikan selaku pangkal rujukan untuk orang mukmin ialah jumlahnya amat banyak, hendak namun periset hendak fokus pada satu buku yang dikaji di pondok madrasah Miftahul Ulum Tempuran Bantaran Probolinggo ialah Buku Mafahim. Kitab Mafahim ialah Kitab yang mangulas mengenai kepercayaan serta tawassul. Buku ini di catat oleh Sayyid Muhammad bin Alawi al- Maliki. Dia merupakan seseorang guru yang amat' patuh dalam aspek hadits. Dia ialah generasi Rosulullah SAW, ialah putra dari Sayyid Alwi bin Abbas bin Abdul Teragung bin Arif Billah al- Maliki al- Hasani al- Idris. Nasab dia bersambung lalu hingga pada Sayyid Idris al- Azhar bin Idris al- Akbar bin Abdullah al- Kamil bin Hasan al- Muhanna bin 
Hasan Sayyidina' Ali bin Abi Tholib suami dari Sayyidatina Fatimah az- Zahra binti Rosulullah SAW. Dia memiliki julukan Muhammad yang mashur dengan julukan Muhammad' Alawi alMaliki al- Hasani, julukan itu sebab dinisbahkan pada papa serta kakeknya Sayyid' Alawi serta alMaliki al- Hasani. Dia dilahirkan di kota yang agung ialah Makkah al- Mukarromah pada tahun $1367 \mathrm{H}$ ( 1947 Meter).

Pondok pesantren Miftahul ulum adalah salah satu dari beberapa pondok pesantren yang ada dikabupaten Probolinggo yang terletak di Desa Tempuran,Kecamatan Bantaran, Kabupaten Probolinggo. Didirikan oleh Ky Muhammad pada tahun 1997 M yang sekaligus menjadi pengasuhnya pertama di Pondok Pesantren Miftahul Ulum yang kemudian dilanjutkan oleh putra penerus yaitu Ky Moch Muchlis. Jumlah santri pondok pesantren pertama kali sebanyak 3 orang yang kemudian dari tahun ke tahun terus bertambah, sekarang jumlah santri pondok pesantren sebanyak 113 dari santri laki-laki dan satri perempuan yang berasal dari berbagai daerah dipulau Jawa maupun di luar Jawa. Awal berdirinya Pondok miftahul ulum ini karena ada nya wali murid yang meminta kepada beliau pendiri (Ky Muhammad) Agar di Kasih pembelajaaran anaknya untuk memahami agama islam. Mereka diajarkan tentang ilmu agama secara menyeluruh, akan tetapi tidak hanya ilmu agama yang diberikan, melainkan ilmu umum yang lainnya. Santri diajarkan beberapa kitab klasikal mulai dari kitab dasar hingga kitab-kitab yang lebih luas keterangannya, salah satu nya adalah kitab hamami zaadah (tafsir yaasin).

Program pengajian yang ditawarkan oleh pondok pesantren Miftahul Ulum Tempuran Bantaran Probolinggo beragam. Bagi para santri salah satu kajian kitabnya menggunakan kitab Mafahim yang mana kitab tersebut sangatlah penting untuk dipelajari dan dipahami,karena untuk buat menguatkan faham ahlus sunnah wal jama' ah santri supaya tidak campur tangan kealiran yang menyimpang. Cocok dengan kerangka balik itu, hingga peneliti amat terpikat untuk mengambil sebuah judul ialah" Pelaksanaan Pembelajaran Kitab Mafahim dalam tingkatkan faham Ahlus Sunnah wal Jama' ah santri di Pondok Madrasah Miftahul Ulum Tempuran Bantaran Probolinggo".

\section{Metode (15\%)}

Pendekatan yang digunakan dalam penelitian ini adalah pendekatan kualitatif deskriptif karena penelitian yang akan dilakukan akan berusaha mendeskripsikan tentang pembelajaran kitab mafahim dalam meningkatkan faham ahlus sunnah wal jama'ah santri di pondok pesantren Miftahul Ulum Tempuran Bantaran Probolinggo, alasan menggunakan pendekatan ini karena data yang dikaji atau diteliti berupa katakata tertulis atau lisan dari orang-orang atau perilaku yang diamati.

Penelitian yang dipakai merupakan penelitian lapangan( field research). Jenis penelitian ini memakai field research ialah penelitian langsung, bisa pula selaku pendekatan besar dalam penelitian kualitatif ataupun selaku tata cara buat mengakulasi informasi kualitatif sebab riset ini berupaya buat mendefinisikan mengenai tujuan, materi, metode dan evaluasi dalam melakukan Pembelajaran kitab mafahim dalam meningkatkan faham ahlus sunnah wal jama'ah santri di pondok pesantren Miftahul Ulum Tempuran Bantaran Probolinggo.

Adapun yang dijadikan tempat penelitian adalah Pondok Pesantren Miftahul Ulum yang beralamatkan di Jl. KH Anom RT 13 RW 04 Dusun Lampean, Desa Tempuran, Kecamatan Bantaran, Kabupaten Probolinggo, Provinsi Jawa Timur.

Subyek penelitian merupakan paling penting dalam riset ini yang mempunyai serta mengenali yang sudah diawasi. Pada bagian ini dikabarkan tipe informasi serta pangkal informasi penjelasan itu mencakup informasi apa saja yang mau didapat siapa yang akan dijadikan informan ataupun poin penelitian Bagaimana serta hendak dicari dan dijaring alhasil validitasnya bisa dipastikan.

Sumber informasi riset ialah aspek berarti yang jadi estimasi dalam determinasi tata cara pengumpulan informasi, tidak hanya tipe informasi. Pangkal informasi merupakan subyek riset tempat informasi melekat. Pangkal informasi berbentuk barang, aksi orang, tempat, serta serupanya. Pangkal informasi pada riset yang dicoba ini berbentuk pangkal orang selaku pangkal pokok yang terdiri dari: Penjaga, Ustadz, Pengasuh, Santri.

\section{Hasil dan Pembahasan (70\%)}

Perencanaan Pembelajaran Kitab Mafahim 
Pemograman atau planning ialah aktivitas yang sangat pokok dalam bermacam aktivitas yang wujudnya aksi mengakomodir seluruh suatu yang berhubungan dengan profesi itu buat mencapai sasaran atau tujuan yang maksimal. Pemograman ialah penentuan seberinda aksi serta pangkal energi dalam usaha maraih sasaran atau tujuan.

Dalam membuat serta memutuskan ketetapan mengenai aktivitas penataran,pengajar selaku pengelola aktivitas penataran pastinya telah mempersiapkan alternatif- alternatif opsi buat mencapai tujuan. Tidak hanya itu, Pengajar pula wajib sanggup mengatur multi pangkal, bagus pangkal energi, pangkal anggaran, ataupun pangkal berlatih. Untuk pengajar khasiat pemograman selaku pengawasan kepada diri sendiri biar bisa membenarkan pola pengajaran serta selaku pijakan menurutnya.(Saifulloh and Darwis, 2020)

\section{a. Pelaksanaan Pembelajaran Kitab Mafahim \\ 1) Penguasaan Materi \\ a) Definisi Kafir}

Dengan cara harfiah, tutur ateis berawal dari pangkal tutur kaf, fa, ra yang berarti menutupi. Dari penafsiran itu setelah itu timbul sebagian pernyataan yang pada dasarnya dikembalikan pada penafsiran itu. Misalnya malam diucap ateis sebab beliau menutupi siang, orang tani diucap ateis sebab menutupi bibit dengan tanah, pula awan diucap ateis sebab beliau menutupi mentari. Dalam perkamusan Ibnu Mandzur juga begitu, dimaksud selaku menutup ataupun penutupan pada arti awal mulanya. Pada arti berikutnya, Ibnu Mandzur mengkategorisasikan arti kufr begitu juga dituturkan oleh para pakar selaku selanjutnya:(1) selaku lawan kata(antonim) dari kepercayaan;( 2) selaku lawan kata(antonim) dari terima kasih;( 3) kufr al- inkar ialah membelit- belitkan Allah Swt. dengan batin serta lisannya; (4) kufr al- juhud ialah membelit- belitkan ahadiat Allah Swt. dengan lisannya;( 5) kufr al- mu' anadatialah mengenali Allah Swt. dengan batin serta lisannya, namun sungkan merangkul agama- Nya. (Adam, 2018)

\section{b) Status khaliq dan makhluq}

Perbandingan antara status Khaliq serta makhluq merupakan garis pemisah antara ateis serta kepercayaan. Kita beriktikad kalau orang mencapuradukkan kedua status ini berarti ia sudah ateis. Tiap- tiap dari kedua status di atas mempunyai hak- hak khusus. Insan dimaksud selaku seluruh buatan si Khaliq yang terdapat dialam raya ini. Tutur insan berawal dari bahasa arab, ialah Khalaqa yang maksudnya menghasilkan ataupun menghasilkan. Tutur ini berawal dari pangkal tutur yang tertata dari graf kha, lam, qaf yang maksudnya memutuskan suatu. Didalam AlQur'an, Allah sudah mengatakan kalau la merupakan Tuhan yang Maha Satu. Agama kalau tidak ada Tuhan selain Allah hendak tertancap lewat bukti syahadat.(Tahir, 2016)

Keyakinan pada Tuhan Yang Maha Satu, merupakan pemurnian keyakinan par- excellencel sangat besar), dengan keyakinan itu orang memperoleh arti yang terkini serta format yang lebih dalam mengenai jalinan yang dipunyanya dalam alam sarwa ini. Tauhid adalah cara pembebasan orang yang tidak tara. Cara ini melingkupi segala ikatan yang terdapat, semacam ikatan antara orang dengandi rinya, antara orang dengan sesama, serta antara orang dengan alam sarwa, yang ialah lokus sedangkan menurutnya dalam kehidupan duniawi ini. Dengan rancangan tauhid, seluruh ikatan ikatan itu telah memperoleh faktor transendensinya. Seluruh ikatan itu dibangun kembali, cocok dengan kaidah- kaidah yang sudah didetetapkan Tuhan. (Prasetiya, Rofi and Setiawan, 2018)

\section{c) Bid'ah}

Tutur bid'ah dengan cara bahasa mempunyai 2 tutur asal,awal atau al- bad'u didapat darifi'il madly atau bada'a,serta keduaatau al- ibda' yang didapat dari fi' il madly atau abda' a. Kedua tutur itu mempunyai arti yang serupa, ialah tutur atau' contoh yang mempunyai arti tumbuhnya suatu tanpa terdapatnya ilustrasi tadinya, yang diada- adakan, serta ialah buatan yang tadinya tidak terdapat. Sebaliknya bagi sebutan kalau seluruh suatu yang terkini sehabis era Rasulullah saw diucap bid' ah, bagus yang bertabiat baik ataupun jelek.(Supani, 2008)

\section{d) Tasawwuf}

Dunia Barat melabeli kebatinan dengan merek sufisme, julukan ini spesial buat kebatinan Islam. Di bumi Islam kebatinan tercantum salah satu patuh ilmu. Patuh ini sudah menemukan atensi periset, bagus dari Barat, Timur, mukmin ataupun non mukmin. Ada pula kesahan kedatangan kebatinan selaku satu aspek riset ilmu sedang diragukan, terlebih di dalam angkatan laut(AL) $\mathrm{Qu}$ ' ran serta angkatan laut(AL) Hadits tidak sempat menyinggung tutur ini. Angkatan laut(AL) Qusyairi sendiri selaku pengarang buku 
kebatinan klasik tidak sempat mengatakan kalau Hasan Basri merupakan seseorang Sufi.

Subjek kebatinan merupakan Tuhan sebab yang dibahas, dituntut serta dicari merupakan Tuhan. Tata cara kebatinan merupakan mujahadah dengan bersarana batin, sebaliknya tujuannya merupakan mau terletak sedekat bisa jadi dengan Tuhan. Bagi para sufi, Tuhan merupakan zat yang bersih serta bersih, sebaliknya orang penuh dengan bercak serta kotor. Kotor dalam perspektif kebatinan merupakan kesalahan, orang penuh dengan kesalahan tak mungkin bisa dekat dengan Tuhan. Supaya dekat dengan Tuhan, bersihkanlah jiwamu dari seluruh kesalahan, metode pembersihannya haruslah ditempuh lewat mujahadah, ialah melawan hawa hasrat, individualistis, serta sebagainya.

Kebatinan lumayan susah buat didefinisikan serta diformulasikan sebab mempunyai permasalahan yang lumayan lingkungan. Apabila diamati dari bidang asal tutur saja, telah mencuat bermacam berbagai opini. Terdapat yang berkata kalau tutur itu berawal dari(1)suffah,suffu,safa sophosserta suf.Suffah ialah suatu serambi dalam mesjid Nabawidi Madinah,tempatterkumpul segerombol kawan rasul yang mengistimewakan dirinya buat beribadah serta berjihad di jalur Allah,( suffu), barisan depan dalam beribadah pada Allah( 3) safa ialah bersih, bersih serta jernih, ialah dari kekotoran jiwa serta yang ke( 5) Suf, bulu biri- biri, kain agresif yang digunakan para sufi buat membuktikan kesahajaan dalam hidup.(Farida, 2011)

\section{e) Tawassul}

Ada pula tutur tawassul( bahasa Arab, berikutnya ditulis tawasul) merupakan wujud mashdar( tutur barang abstrak atau abstract noun) dari fi' il( tutur kegiatan atau verb) dari tawassalayatawassalu- tawassulan, suatu tutur yang seakar dengan tutur ikatan, yang berarti sesuatu jalur yang berperan selaku perantara buat mendekatkan diri pada yang lain. Dalam perihal ini pasti maksudnya merupakan sesuatu jalur ataupun upaya buat mendekatkan diri pada Allah Swt dengan memakai ikatan( perantara), semacam orang ataupun insan yang lain supaya terkabul apa yang ia mau.(As, 2018)

\section{2) Metode Pembelajaran Kitab Mafahim}

Tata cara ialah sesuatu perlengkapan dalam penerapan pembelajaran, ialah yang dipakai dalam penyampaian modul itu. Modul pelajaran yang gampang juga terkadang susah berkembangserta susah diperoleh oleh partisipan ajar, sebab metode ataupun tata cara yang digunakannya kurang pas. Tetapi, kebalikannya sesuatu pelajaran yang susah hendak gampang diperoleh oleh partisipan ajar, sebab penyampaian serta tata cara yang dipakai gampang dimengerti, sesuai serta menarik. (Maesaroh, 2013)

\section{3) Media Pembelajaran Kitab Mafahim}

Alat berasal dari bahasa Latin" biasa" yang berarti" perantara" ataupun " pengantar". Lebih lanjut, alat ialah alat agen catatan ataupun data berlatih yang akan di informasikan oleh pangkal catatan pada target ataupun akseptor catatan itu. Pemakaian alat bisa menolong pendapatan kesuksesan berlatih.

Ciri-ciri umum dari alat pembelajaran, merupakan:pertama,Alat penataran sama dengan penafsiran peragaan yang berawal dari tutur" badan", maksudnya sesuatu barang yang bisa diraba, diamati serta didengar serta yang bisa dicermati lewat panca indera. Kedua, Titik berat penting terdapat pada barang ataupun keadaan yang bisa diamati serta didengar. Ketiga, Alat penataran dipakai dalam bagan ikatan( komunikasi) dalam pengajaran antara guru serta anak didik. Keempat, Alat penataran merupakan sejenis perlengkapan tolong berlatih membimbing, bagus di dalam ataupun di luar kategori. Kelima, Alat penataran ialah sesuatu" perantara"( biasa, alat) serta dipakai dalam bagan berlatih. Keenam, Alat penataran memiliki pandangan, selaku perlengkapan serta sebagi metode yang akrab pertaliannya dengan tata cara berlatih.(Tafonao, 2018)

\section{b. Evaluasi Pembelajaran Kitab Mafahim}

Penilaian penataran dicoba buat mengenali apakah pemograman penataran yang sudah diformulasikan serta direalisasikan dalam penerapan penataran sudah berhasil ataupun belum. Penilaian hasil berlatih partisipan ajar dicoba oleh pengajar buat memantau cara, perkembangan, serta koreksi hasil berlatih partisipan ajar dengan cara berkelanjutan".Penafsiran yang lain dicetuskan Suharsimi Arikunto, menjelaskan penilaian cara pengajaran merupakan sesuatu susunan aktivitas yang dicoba dengan terencana buat memandang ataupun mengenali seberapa besar tingkatan kesuksesan dari aktivitas yang direncanakan. (Priyatna, 2017)

\section{c. Ahlus Sunnah wal Jama'ah}


Jurnal Edumaspul, 5(2), Year 2021- 559

(Budi Hartonoํㅜ, Benny Prasetiya ${ }^{2}$, Ari Susandi ${ }^{3}$ )

\section{1) Tawassuth}

At- tawasuth tercantum al- l' tidal serta atTawazun, bukan serba kompromistik dengan mengacaukan seluruh faktor( sinkretisme). Pula bukan mengucilkan diri dari menyangkal pertemuan dengan faktor apa-apa. Sebab kepribadian untuk Islam merupakan memanglah semenjak awal Allah SWT. Telah menaruh di dalam Islam seluruh kebaikan, serta seluruh kebaikan itu tentu ada di antara akhir Tatharruf(فرطلتا), watak mengujung, ekstrimisma.

Asumsi mengabungkan seluruh kepribadian yang lain dengan kepribadian at- tawasuth, kalau dengan cara kondisi seluruh kata-kata itu memanglah ujungnya pada arti yang serupa ialah menaruh diri di tenggah-tengah dalam mengalami suatu. Tetapi senantiasa saja dari seluruh kepribadian itu terdapat sekat-sekatnya.

Kepribadianat-tawasuth wajib sanggup dimanifestasikan dalam bermacam aspek, supaya esoknya tindakan serta aksi laris pemeluk Islam bisa dijadikan selaku acuan serta dimensi orang pada umumnya.(Nikmah, 2018)

\section{2) Tawazun}

Tawazun berarti penyeimbang, tidak berat sisi, tidak kelewatan suatu faktor ataupun kekurangan faktor lain. Pola ini dibentuk lebih banyak buat persolanpersoalan yang berukuran sosial politik. Dalam bahasa lain, lewat pola ini Aswaja mau menghasilkan integritas serta kebersamaan sosial pemeluk.(Ibrahim, 2015)

\section{3) Tasamuh}

Kesabaran merupakan wujud( mubalaghah) dari" samaha" yang dalam bahasa Indonesia lazim dimaksud" antara rasa" ataupun dalam sebutan diucap keterbukaan. Praktisnya, kesabaran merupakan gampang dalam berhubungan, fleksibel, bersikap ringan tidak mengalutkan. Sebutan" kesabaran" mulai terkenal pada fasefase akhir era yang kemudian, oleh para cendikiawan mukmin sebutan ini digunakan buat mengatakan satu tindakan di mana seseorang mukmin tidak merasa terbebani dengan kondisi keberaga- maan orang lain ataupun orang lain yang berlainan agama, tidak ekstrem( kelewatan). Dalam bahasa Arab maksud kesabaran merupakan" bersama legal bagus, lemas halus, serta silih toleran." Dalam penafsiran sebutan biasa, kesabaran merupakan" tindakan adab baik dalam pergaulan, di mana ada rasa silih menghormati antara sesama orang dalam batas- batas yang digariskan oleh anutan

Islam".(Jamaruddin, 2016)

\section{4) Amar ma'ruf nahi munkar}

Menginstruksikan kebaikan( amar Ma'ruf) serta mencegah kemungkaran( nahi munkar) merupakan tiang- tiang berarti dalam agama. berdasar dengan agama buat menginstruksikan pada yang bagus yang cocok dengan syariat serta mencegah kemungkaran yang dilarang ataupun ialah perihal yang kurang baik bagi syariat agama. Amar ma' ruf serta nahi munkar ini dapat dilaksanakan dengan sempurna sebab rasulullah sudah diutus buat melengkapi adab orang. (Devy Habibi, Harimulyo, Prasetya and Muhammad, 2021)

Bila orang memandang kemunkaran serta tidak dapat merubahnya,diawatirkan Allah hendak melimpahkan hukuman siksa-Nya dengan cara menyeluruh, bila kemaksiatan telah jadi Kerutinan di tengah warga, serta banyak orang yang beragama tidak hirau serta tidak berupaya buat menghindari kemaksiatan itu, hingga Allah swt hendak menibankan hukuman pada sesuatu kalangan tanpa memandang bagus banyak orang yang kejam ataupun banyak orang yang beragama.

Perintah melaksanakan kebaikan serta menghindari kemunkaran itu harus dicoba dengan melimpahkan semua kemampuan yang pada diri ataupun golongan. Dengan cara empiris meyakinkan sebenarnya bila kemunkaran didiamkan sedemikian itu saja serta tidak diganti, hingga tidak lama setelah itu kemunkaran itu hendak dikira suatu yang lazim, alami serta digarap dengan cara beramai- ramai. Bila perihal itu terjalin, hingga kemunkaran itu susah buat dihilangkan. (Sabir, 2015)

Berdasarkan hasil penelitian lapangan yang peneliti lakukan di Pondok Pesantren Miftahul Ulum, Tempuran, Probolinggo terkait Pembelajaran kitab Mafahim dalam meningkatkan faham Ahlussunnah Wal Jamaah dapat diuraikan $P$

Perencanaan, pelaksanaan, dan evaluasi. Perencanaan pembelajaran kitabMafahim di pondok pesantren ialah seseorang ustadz wajib dapat memusatkan, memotivasi santri biar santri dapat aktif, inovatif, serta suka kala cara penataran. Sebab perencanaan penataran ialah suatu yang telak wajib dicoba oleh ustadz tiap hendak melaksanakan cara pembelajaran. Pelaksanaan pembelajaran kitabMafahim yang 
diterapkan di Pondok Pesantren Miftahul Ulum adalah sorogan dan bandungan.

Pemakaian tata cara penataran buku klasik wajib mencermati ciri modul pelajaran, situasi santri, dan alat serta infrastruktur. Selanjutnya evaluasi pembelajaran kitab Mafahim yang dilakukan dengan dua langkah. Langkah pertama, evaluasi dilakukan diakhir pembelajaran yaitu pada waktu akhir semester dengan memberikan tes tulis. Kedua, dengan melihat langsung perkembangan para santri apakah sudah menanamkan nilai- nilai Islam ahlussunnah wal jama' ah dengan bukti peserta didik mengamalkan amaliah- amaliah ahlussunnah wal jama' ah dalam kehidupan tiap hari, peserta didik mengamalkan prinsip- prinsip ahlussunah wal jama' ah.

\section{Simpulan (5\%)}

Adapun hasil penelitian ini bisa disimpulkan bahwa dalam melangsungkan pembelajaran harus melakukan sebuah perencanaan pembelajaran dengan memberikan arahan, memotivasi santri biar santri dapat aktif, inovatif, serta suka kala cara pembelajaran.Kemudian dilakukan sebuah pelaksanaan pembelajaran dengan sistem yang telah direncanakan. Yang terakhir evaluasi pembelajaranyang dilakukan diakhir pembelajaran yaitu pada waktu semesteran dengan memberikan tes tulis dan pengamatan langsung terhadap santri.

\section{Daftar Pustaka}

[1] Adam, H. F. (2018) 'Konsep Kafir dalam Alquran: Studi Atas Penafsiran Asghar Ali Engineer', Peradaban dan Pemikiran Islam, 2(2).

[2] Akbar, A. and Ismail, H. (2018) 'METODE PEMBELAJARAN KITAB KUNING DI PONDOK PESANTREN DAARUN NAHDHAH THAWALIB BANGKINANG', Ilmiah Keislaman, 17(1).

[3] As, A. (2018) 'MEMBACA FENOMENA ZIARAH WALI DI INDONESIA: MEMAHAMI TRADISI TABARRUK DAN TAWASSUL', Al Banjari, 17(2).

[4] Devy Habibi, Harimulyo, M. S., Prasetya, B. and Muhammad (2021) 'Nilai-Nilai Pendidikan Akhlak Dalam Kitab Risalatul Mu'awanah Dan Relevansinya', Penelitian IPTEK, 6(1).
[5] Farida, M. (2011) 'PERKEMBANGAN PEMIKIRAN TASAWUF DAN IMPLEMENTASINYA DI ERA MODERN', Substantia, 12(1).

[6] Ibrahim, R. (2015) 'DERADIKALISASI AGAMA DALAM PEMAHAMAN TEKS-TEKS LITERATUR PENDIDIKAN PESANTREN', Wahana Ademika, 2(2).

[7] Jamaruddin, A. (2016) 'MEMBANGUN TASAMUH KEBERAGAMAAN DALAM PERSPEKTIF AL-QUR'AN', Toleransi, 8(2).

[8] Khosiah, N. (2020) 'No Title', pp. 28-41.

[9] Maesaroh, S. (2013) 'PERANAN METODE PEMBELAJARAN TERHADAP MINAT DAN PRESTASI BELAJAR PENDIDIKAN AGAMA ISLAM', Kependidikan, 1(1).

[10] Nikmah, F. (2018) 'MPLEMENTASI KONSEP AT TAWASUTH AHLUS- SUNNAH WAL JAMA'AH DALAM MEMBANGUN KARAKTER ANAK DI TINGKAT SEKOLAH DASAR (STUDI ANALISIS KHITTAH NAHDLATUL ULAMA)', Tarbawi, 15(1).

[11] Prasetiya, B., Rofi, S. and Setiawan, B. A. (2018) 'Penguatan Nilai Ketauhidan Dalam Praktis Pendidikan Islam', Islamic Education, 3(1).

[12] Priyatna, M. (2017) 'MANAJEMEN PEMBELAJARAN PROGRAM KULLIYATUL MU'ALLIMIN AL-ISLAMIYAH (KMI) DI PONDOK PESANTREN MODERN AL-IHSAN BALEENDAH BANDUNG', Pendidikan Islam, 6(11).

[13] Rasikh, A. (2018) 'PEMBELAJARAN KITAB KUNING PADA PONDOK PESANTREN KHUSUS AL-HALIMY DESA SESELA KABUPATEN LOMBOK BARAT', Penelitian Keislaman, 14(1).

[14] Sabir, M. (2015) 'Amar Ma'ruf Dan Nahi Mungkar', Potret Pemikiran, 19(2).

[15] Saifulloh, A. M. and Darwis, M. (2020) 'MANAJEMEN PEMBELAJARAN DALAM MENINGKATKAN EFEKTIVITAS PROSES BELAJAR MENGAJAR DI MASA PANDEMI COVID-19', Bidayatuna, 3(2).

[16] Supani (2008) 'PROBLEMATIKA BID'AH: KAJIAN TERHADAP DALIL DAN ARGUMEN PENDUKUNG SERTA PENOLAK ADANYA 
Jurnal Edumaspul, 5(2), Year 2021- 561

(Budi Hartono1, Benny Prasetiya ${ }^{2}$, Ari Susandi ${ }^{3}$ )

BID'AH HASANAH', Penelitian Agama, 9(2), pp. 218-249.

[17]

Susandi, A. (2016) “" Pengembangan Pendidikan Karakter Bangsa Berbasis Kearifan Lokal dalam Era MEA " SEMINAR NASIONAL PENDIDIKAN 2016

Pengembangan Pendidikan Karakter Bangsa Berbasis Kearifan Lokal dalam Era MEA "', 1.

[18] Syafe'i, I. (2017) 'PONDOK PESANTREN: LEMBAGA PENDIDIKAN PEMBENTUKAN KARAKTER', Pendidikan Islam, 8(1).

[19] Tafonao, T. (2018) 'PERANAN MEDIA PEMBELAJARAN DALAM MENINGKATKAN
MINAT BELAJAR MAHASISWA', Komunikasi Pendidikan, 2(2).

[20] Tahir, G. (2016) 'Pluralitas Makhluk dan Keesaan Khaliq', Adabiyah, 16(2).

\section{Profil Penulis}

Nama saya Budi Hartono saya dilahirkan pada tanggal 06 Agustus 1997 di Probolinggo. Pada tahun 2010 saya lulus sekolah dasar di SDN Jerebeng 1. Tahun 2013 Lulus MTs. Roudlotut Tholibin. Pada Tahun 2016 Lulus SMA Sunan Giri Kademangan Kota Probolinggo. Pada Tahun 2018 saya masuk kuliah pendidikan islam di STAIM Probolinggo untuk mendapatkan gelar sarjana Strata satu. Alamat email csantony48@gmail.ccom 